\title{
Soil Degradation Risk Prediction Integrating RUSLE with Geo-information Techniques, the Case of Northern Shaanxi Province in China
}

\author{
Mushtak T. Jabbar and Xiaoling Chen \\ State Key Laboratory of Information Engineering in Surveying, Mapping and Remote Sensing \\ (LIESMARS) Wuhan University, Wuhan 430079, People's Republic of China
}

\begin{abstract}
This research integrated the Revised Universal Soil Loss Equation (RUSLE) with RS, GIS and GPS techniques to quantify soil erosion risk and the northern part of Shaanxi province in China was taken as a case. A system was established for rating soil erodibility, slope length/gradient, rainfall erosivity and conservation practices. The rating values served as inputs into a modified Revised Universal Soil Loss Equation (RUSLE) to calculate the risk for soil degradation processes, namely, soil water erosion. Two Landsat TM senses in 1987 and 1999, respectively, were used to produce land use/ cover maps of the study area based on the maximum likelihood classification method. These maps were then used to generate the conservation practice factor in the RUSLE. ERmapper and Arc/Info software were used to manage and manipulate thematic data, to process satellite images and tabular data source. In term of statistic analysis $3985.9 \mathrm{~km}^{2}(33.12 \%)$ of land area had slight to moderate soil erosion risk, $1583.5 \mathrm{~km}^{2}(13.16 \%)$ had moderately high soil erosion risk, $2941.4 \mathrm{~km}^{2}$ (24.44\%) had high soil erosion risk and $3522.1 \mathrm{~km}^{2}(29.27 \%)$ of the total land area was in a very high soil erosion risk. The study area, in general, is exposed to high risk of soil water erosion.
\end{abstract}

Key words: Geoinformation Techniques, Soil Erosion, RUSLE, Shaanxi, China

\section{INTRODUCTION}

Geoinformation Techniques or 3S Techniques (RS, GIS and GPS) are technologies for collecting and dealing with geographic information. They have percolated into common man's life since the utility of these technologies have a variety of uses right from agriculture, desertification study, forestry, archeology, disaster management, environment, geology, health, land information system, transportation, urban and rural development, telecommunication, to name a few. Geoinformation Technique plays a vital role in mapping inaccessible area on the earth [1].

Soil degradation is one of the most important challenges facing mankind. The problem is as old as the settled agriculture. Worldwide concern has been emphasized recently. Soil degradation was defined as the decline of soil quality caused through its misuse by humans $[2,3]$ refered to soil degradation as the diminution of soils current and/or potential capability to produce quantities or qualities of goods or serviced as a result of one or more degradation processes. Olsen [4] stated that most ancient civilizations flourished on fertile soil and that soil degradation was responsible for their decline.

Soil water erosion is also a severe kind of land degradation. According to Agenda 21, referring to a remote sensing survey in 1990, China's soil erosion area was corresponding to $3,670,000$ square kilometers, covering about $38 \%$ of the total land area. Annual soil loss was said to account for $5 \times 10^{6}$ tons; 70,000 ha of arable land were lost every year by soil erosion. According to the State Science and Technology Commission (referred to by UNDP) between 1985 and 1994 , about 360,000 ha of farmland were annually affected by top-soil loss [5]. In the northern Wei River Valley of Shaanxi Province in China, soil erosion has been extremely serious, affects $130,000 \mathrm{~km}^{2}$ (67\% of Shaanxi Province). Soil loss was estimated at 850 million $\mathrm{t}_{\text {year }}{ }^{-1}$ and average erosion rate was about $6500 \mathrm{t} \mathrm{km}^{-2}$ year $^{-1}$ in the Loess Plateau of Shaanxi and sediment concentrations in the middle reaches of the Yellow River in China (the loess plateau) approached $700 \mathrm{~kg} \mathrm{~m}^{-3}$ (about $50 \%$ by weight) [6].

The professional methodology for soil degradation assessment $[3,7]$ was found to be a successful mean to identify, map and monitor the potential and present status of soil degradation. This methodology is a base to be applicable at universal regional, detailed and very detailed levels. Climatic data, soil condition, topography and human activity are the main inputs for assessment of soil degradation processes.

The Geographic Information System (GIS) is an information technology that stores, analyses and displays both spatial and non spatial data [8]. Among a lot of GIS systems, ARC/INFO and ArcView are rather comprehensive packages that allow using their storage, editing, data management and plotting functions.

The aim of this study is to construct a Geographic Information System containing environmental 
parameters influencing the regional and global changes, with focus on soil degradation problems in the northern part of Shaanxi province in China.

\section{MATERIALS AND METHODS}

The study area, located in the northern part of Shaanxi province, lies within longitude $109^{\circ} 00^{\prime}$ to $110^{\circ} 00^{\prime} \mathrm{E}$ and from latitude $38^{\circ} 40^{\prime}$ to $37^{\circ} 20^{\prime} \mathrm{N}$. The area is 158 $\mathrm{km}$ long (from north to south) and $87 \mathrm{~km}$ wide (from east to west) and has a total area of $13746 \mathrm{~km}^{2}$. In order to study the development of soil degradation, Yulin, Jinbain, Hengshan and Mizhi cities have been selected as a study area. The cities are situated in the northern part of Shaanxi province. The area is located in a typical transitional zone (continental monsoon climate zone). The images have been acquired on $1^{\text {st }}$ September and $24^{\text {th }}$ October, 1987 and in August and October, 1999. All the five thematic layers are generated in GIS environment at a scale of 1:250,000. The softwares used for this study are Arc/Info and ERmapper imagine.

Remote Sensed Image Preprocessing: Two windows of $6967 \times 5968$ pixels from each scene, covering the study area, were used in this study (Landsat TM). In order to perform the geometric correction of the images, the Geodetic Datum WGS84 and map projection NUTM49 coordinate system were built into the vector using Linear method and the resampling method chosen was nearest-neighbour that preserved original reflectance value, Several Control Point (SCP) coordinates had to be collected. ERmapper system was used for geometric correction and some image processing. The images were digitally enhanced using "high pass filter" technique. ERmapper software was used to classify, compute the NDVI. Iso-clustering classification technique was used to classify the NDVI image into six vegetation density classes to produce 14 polygons. The classified image file was converted to ARC/INFO vector format.

Field Sampling and Model Parameter Extraction: Representative soil samples from northern part of Shaanxi province were collected during the study period from three typical soils of each polygon. Important physical and chemical properties of the soils were listed in Table 1 by the procedures of Black [9]. Values for average wind velocity $(\mathrm{m} / \mathrm{s})$, rainfall $(\mathrm{mm})$, temperature $\left({ }^{\circ} \mathrm{C}\right)$ and evaporation $(\mathrm{mm})$ data were obtained for the investigated location according to information recorded during the period 1987-1999 from four meteorological stations. The universal soil loss equation (RUSLE) was adopted for the assessment of Soil water erosion. The equation result is as follows:

$A=F(K * R * L S * C * P)$
Where:

$A$ is the soil loss in $\mathrm{tha}^{-1} \mathrm{y}^{-1}$

$\mathrm{F}$ is the function;

$\mathrm{K}$ is the soil erodibility factor ( $\mathrm{t} \mathrm{ha} \mathrm{h} \mathrm{ha} \mathrm{mJ}^{-1} \mathrm{~mm}^{-1}$ );

$R$ is the rainfall-runoff erosive factor in $\mathrm{mJ} m$ $\mathrm{ha}^{-1} \mathrm{~h}^{-1} \mathrm{y}^{-1}$

$L$ is the slope length factor; $S$ is the slope steepness factor;

$\mathrm{C}$ is the cover and management factor;

$P$ is the conservation practice factor.

The formula describes the processes only approximately and the values assigned to each factors are approximate in the present state of knowledge. These values are merely giving an approximate indication of the magnitude of degradation $[3,7]$.

More data were collected or calculated and entered into the GIS system. ArcView system is capable to use different information layers for different purposes (Table 2). The principle thematic layers are the soil map and all other information is related to its soil polygons. A master tic file was created, with 50 tic points, for geometric correction. The coordinates were converted to the universal transverse mercator (UTM) system using the ARC/INFO software. ARCEDIT was used to edit each information layer and to assign attributes to each polygon. Tables program was also used to assign additional attributes to soil polygon. Other information layers were transferred from ERmapper software to the ARC/INFO system. JOINITEM function of "TABLES" program was used to have all needed attributes in one polygonal attribute table. Calculation function was used to compute the Universal Soil Loss Equation (RUSLE) for all degradation processes. ARC PLOT program was used to plot maps of soil degradation risk and present state of soil degradation.

Determining RUSLE Factors Values: Numerical values were assigned to each soil polygon in the polygon attribute table of the soil coverage layer. The values were chosen according to the following parameters:

Soil Erodibility Factor (K): The $\mathrm{K}$ values were usually estimated using the soil erodibility nomograph method [10]. This method uses \% silt plus very fine sand $(0.002-0.1 \mathrm{~mm}), \%$ sand $(0.1-2 \mathrm{~mm}), \%$ organic matter and soil structure and permeability class to calculate $\mathrm{K}$. However, there is lack of structure and permeability class data in the soil survey data source. Therefore, we adapted following equation, which was recommended by RUSLE when lack observation data. The soil erodibility factor was estimated using the equation of Renard et al. [11] as follows:

$\mathrm{K}=7.594\left\{\left(0.0034+0.0405 \exp \left(-1 / 2\left(\log \left(\mathrm{D}_{\mathrm{g}}\right)\right.\right.\right.\right.$

$\left.\left.\left.+1.659 / 0.7101)^{2}\right)\right)\right\}$ 
$D_{g}=\exp 0.01$ sum (fi- $\left.\ln \mathrm{mi}\right)$

Where:

$\mathrm{K}$, soil erodibility factor ( $\mathrm{t}$ ha $\mathrm{h} \mathrm{ha} \mathrm{h}^{-1} \mathrm{~mJ}^{-1} \mathrm{~mm}^{-1}$ ); $\mathrm{D}_{\mathrm{g}}$, mean geometric particle diameter $(\mathrm{mm})$;

fi, primary particle size fraction (\%);

$\mathrm{mi}$, arithmetic mean of the particle size limits of that size $(\mathrm{mm})$;

Rainfall Erosivity Factor (R): The rainfall-runoff erosivity factor $(R)$ refers to climate (rainfall) factor. The agents for the erosion are raindrops and flowing water. Raindrop, rain splash or splash erosion is the process of erosion on barren soil surfaces. Rainfall data were collected from four meteorological stations in Northern part of Shaanxi for the years 1987 and 1999. The estimation of annual rainfall erosivity was done using the regional (statistical) regression indices (modified Fournier equation). The rainfall database obtained from the Yulin meteorological office includes the rainfall data for the years 1987 and 1999. Rainfall erosivity was determined by using Rrain formula [12].

$$
\mathrm{R}_{\mathrm{and}}=\left[4.17 \times \sum_{i=1}^{12}\left(P^{2} / P\right)\right] 152
$$

Where,

$P_{i}$ is the month $i$ average rainfall $(\mathrm{mm})$

$P$ is the annual average rainfall $(\mathrm{mm})$ and

$R_{\text {ann }}$ is the approximate annual average $R$ rainfall

erosivity factor value. Table 3 shows the annual

average rainfall and rainfall ersosivity factor.

Topographic Factors (L and S): The slop factors (LS) refer to topographic and/or relief factor. In the computation of the LS factors, the topographic factors, $\mathrm{L}$ and $\mathrm{S}$ factor are usually considered together. The slope length factor $L$, computes the effect of slope length on erosion and the slope steepness factor $S$ and computes the effect of slope steepness on erosion.

To describe the influence of slope steepness, Liu et al. [13] researched steep slopes data from China. Based on synthesizing the results presented by Liu et al. [13] and Nearing [14] produced a single continuous function for S:

$$
s=-1.5+\frac{17}{\left(1+e^{2.3-6.1 \sin \theta}\right)}
$$

where $\theta$ is the slope angle (degrees).

Slope length is defined as the horizontal distance from the origin of overland flow to the point where either the slope gradient decreases to a point where deposition begins, or runoff becomes focused into a defined channel $[10,11]$.

To model upslope drainage area, the steepest descent algorithm (single flow), multiple flow algorithm [15] and the flux decomposition method was proposed in the literature to calculate the contributing area of each grid cell in a grid-based DEM. Desmet and Govers [16, 17] tested the three algorithms in the program USLE2D.EXE, which is designed to calculate the LSfactor in the USLE or RUSLE from a grid-based DEM and provides the user with a number of options with respect to selecting both a hydrological flow routing algorithm and a slope length and steepness algorithm [18].

The unit contributing area for the slope length value was then substituted as the slope length within the equation provided by Foster and Wischmeier [19], with each of the grid cells within the DEM considered as a slope segment having uniform slope. Substituting the values for cell outlet and cell inlet into the Foster and Wischmeier [19] equation solves the slope length $\mathrm{L}$ component:

$$
L_{i, j}=\frac{A_{i, j-\text { out }}^{m+1}+A_{i, j-\text { in }}^{m+1}}{\left(A_{i, j-\text { out }}-A_{i, j-\text { in }}\right)(22.13)^{m}}
$$

Where, $L_{(i, j)}$ is the slope length factor for the cell with coordinates $(i, j), A_{(i, j-\text { out }}$ is the contributing area at the outlet of the grid cell with coordinates $(i, j), A_{(i, j-i n)}$ is the contributing area at the inlet of the grid cell with coordinates $(i, j)$ and $m$ is the slope length exponent of the USLE S-factor [16]. The LS-factor was consequently determined by multiplying the $S$ and Lfactors in IDRISI to obtain the map of topographic factors.

In order to estimate the impact of slope length and slope steepness on the assessment of soil erosion risk in Yulin at the study area in particular, the following procedure were adopted: Digital Elevation Model DEM map (resolution $30 \mathrm{~m}$ ) of the study area was created by digitizing the topographic map of Yulin (scale 1:250,000). RUSLE-LS factor values were extracted from the DEM files of the study areas by using USLE2D Ver. 4.1 software, Gover 1991 algorithm was used to estimate LS values for the study areas.

Human Factor (Land Use/Cover Factor (C) and Conservation Practice Factor (P)): Cropland and ground conditions vary considerably over time. As a crop grows, increasing amounts of soil surface are protected from rainfall by canopy, while surface residue cover may decrease because of residue decomposition and tillage operations. It is important to predict Soil Loss Ratio (SLR) frequently for the rapidly changing soil and cropping conditions common to most cropland. Incorporating the impact time into the model requires defining some time step over which the other effects can be assumed to remain relatively constant. C-factor map was prepared from Land use/ cover map, which was prepared from supervised classification (Table 4) $[10,20]$. While the RUSLE P-factor reflects the impact 
Table 1: Some Chemical and Physical Properties of Soil Used

\begin{tabular}{|c|c|c|c|c|c|c|c|c|c|}
\hline \multirow[t]{2}{*}{ ID No. } & \multicolumn{5}{|c|}{ Physical properties } & \multicolumn{4}{|c|}{ Chemical properties } \\
\hline & $\begin{array}{l}\text { Sand } \\
\left(\mathrm{g} \mathrm{kg}^{-1}\right)\end{array}$ & $\begin{array}{r}\begin{array}{r}\text { Silt } \\
\left(\mathrm{g} \mathrm{kg}^{-1}\right)\end{array} \\
\end{array}$ & $\begin{array}{c}\text { Clay } \\
\left(\mathrm{g} \mathrm{kg}^{-1}\right)\end{array}$ & Texture & $\begin{array}{l}\text { Bulk } \\
(\mathrm{D} \mathrm{g} \mathrm{cm})\end{array}$ & $\mathrm{pH}$ & $\begin{array}{c}\mathrm{EC} \\
\left(\mathrm{dS} \mathrm{m}^{-1}\right)\end{array}$ & $\begin{array}{r}\mathrm{O} . \mathrm{M} \\
\left(\mathrm{g} \mathrm{kg}^{-1}\right)\end{array}$ & $\begin{array}{c}\mathrm{CaCO}_{3} \\
\left(\mathrm{~g} \mathrm{~kg}^{-1}\right)\end{array}$ \\
\hline 1 & 920.2 & 40.85 & 38.95 & Sandy & 1.689 & 7.25 & 2.52 & 0.502 & 19.0 \\
\hline 2 & 900.4 & 50.82 & 48.72 & Sandy & 1.672 & 7.42 & 1.85 & 0.625 & 16.5 \\
\hline 3 & 880.5 & 59.28 & 60.14 & Sandy & 1.685 & 7.45 & 1.92 & 0.743 & 16.5 \\
\hline 4 & 910.0 & 49.86 & 40.12 & Sandy & 1.669 & 7.29 & 1.95 & 0.855 & 16.5 \\
\hline 5 & 810.0 & 109.8 & 90.25 & Loamy Sand & 1.522 & 7.40 & 2.21 & 1.105 & 12.2 \\
\hline 6 & 800.9 & 108.8 & 90.25 & Loamy Sand & 1.532 & 7.20 & 2.20 & 0.994 & 10.5 \\
\hline 7 & 240.9 & 418.6 & 340.5 & Silty Loam & 1.311 & 7.40 & 2.65 & 1.855 & 10.3 \\
\hline 8 & 240.2 & 429.7 & 330.1 & Silty Loam & 1.295 & 7.70 & 1.60 & 1.892 & 10.1 \\
\hline 9 & 200.3 & 469.0 & 330.7 & Silty Loam & 1.325 & 7.65 & 1.70 & 1.758 & 16.5 \\
\hline 10 & 90.20 & 600.2 & 309.6 & Loamy Clay & 1.191 & 7.90 & 2.50 & 2.709 & 6.2 \\
\hline 11 & 820.5 & 98.70 & 80.80 & Loamy Sand & 1.430 & 7.20 & 1.20 & 0.929 & 4.5 \\
\hline 12 & 240.0 & 489.6 & 270.4 & Silty Loam & 1.212 & 7.80 & 1.40 & 3.706 & 1.9 \\
\hline 13 & 120.5 & 470.4 & 409.1 & Clay Loam & 1.092 & 7.80 & 2.25 & 3.907 & 1.8 \\
\hline 14 & 090.4 & 470.2 & 439.4 & Silty Clay & 0.938 & 7.90 & 2.45 & 4.453 & 1.8 \\
\hline
\end{tabular}

Table 2: GIS Thematic Data Layers

\begin{tabular}{lll}
\hline Information layers & Source & Purpose \\
\hline Classified TM image & TM & Map, updating soil \\
(NDVI) & TM & Rating human activity \\
Irrigation, drainage and river & Topographic maps & Geometric correction \\
Contour map & Topographic maps & Calculating slop percent \\
Climatic data & Meteorological station & Computing climatic factor \\
\hline
\end{tabular}

Table 3: RUSLE-R Factor Values in the Study Areas

\begin{tabular}{llcc}
\hline Meteorological station & Years & Annual rainfall $(\mathrm{mm})$ & Rainfall erosivity factors $\mathrm{R}_{\text {ann }}$ \\
\hline Yulin & 1987 & 345.3 & 146.3157 \\
& 1999 & 361.9 & 156.2695 \\
Jingbian & 1987 & 375.4 & 161.1332 \\
& 1999 & 441.0 & 173.9762 \\
Hengshan & 1987 & 537.8 & 210.7652 \\
& 1999 & 459.2 & 221.9651 \\
Mizhi & 1987 & 550.2 & 273.2873 \\
& 1999 & 487.9 & 259.8956 \\
\hline
\end{tabular}

Table 4: C-factor Value for Different Classes

\begin{tabular}{lc}
\hline Land use class & Average C factor value \\
\hline Forest & 0.003 \\
Bush and grasslands & 0.01 \\
Weak vegetation & 0.60 \\
Sparse vegetation & 0.90 \\
Barren soil & 1.0 \\
Urban areas & 0.0001 \\
Croplands & 0.40 \\
Sand dunes & 1.0 \\
Sand lands & 1.0 \\
Water bodies & 0.0001 \\
\hline
\end{tabular}

Table 5: The Ordinal Categories Soil Erosion and the Area and Proportion of Each Category

\begin{tabular}{lccc}
\hline Erosion risk class & Numeric range $\left(\mathrm{t} \mathrm{ha}^{-1} \mathrm{y}^{-1}\right)$ & Area $\left(\mathrm{km}^{2}\right)$ & Proportion (\%) \\
\hline Slight to moderate & $0-5$ & 3985.9 & 33.12 \\
Moderately high & $5-10$ & 1583.5 & 13.16 \\
High & $10-30$ & 2941.4 & 24.44 \\
Very high & $30-80$ & 3522.1 & 29.27 \\
Extreme & $>80$ & - & - \\
\hline
\end{tabular}


of support practices dealing with the average annual erosion rate. It is the ratio of soil loss with contouring and/or strip cropping to that with straight row farming up-and-down slope. As with the other factors, the Pfactor differentiates between cropland and rangeland or permanent pasture. As the study of this research work to estimate soil erosion using RUSLE modeling was applied in the area of non-agriculture or on natural (geological) erosion, it was considered that there was no conservation practice $(P)$ in non-agricultural areas. Therefore as the conservation practice factor $(\mathrm{P})$ value ranges from $0.0-1.0$ and the highest value is assigned to areas with no conservation practice, the maximum value for $\mathrm{P}$, that is 1.0 , is assigned to this research work area.

\section{RESULTS AND DISCUSSION}

Maps of $K, R, L S, C$ and $P$ factors were integrated within ArcView to generate a composite map of erosion intensity [21]. Figure 1-4 shows Soil erodibility factor average values map (RUSLE_K factor), Rainfall erosivity factor (RUSLE_R factor), Slope Length and Slope Steepness Factors (RUSLE_LS factor) map, (RUSLE_C\&P) factors average values map based on landsat-5 TM images and GPS data, respectively. The layers of RUSLE model were created and integrated within ArcView by an overlay procedure for the study area for the year 1987-1999. Morgan [20, 22] argued that $10 \mathrm{t} \mathrm{ha}^{-1} \mathrm{yr}^{-1}$ was an appropriate boundary measure of soil loss over which agriculturists should be concerned.

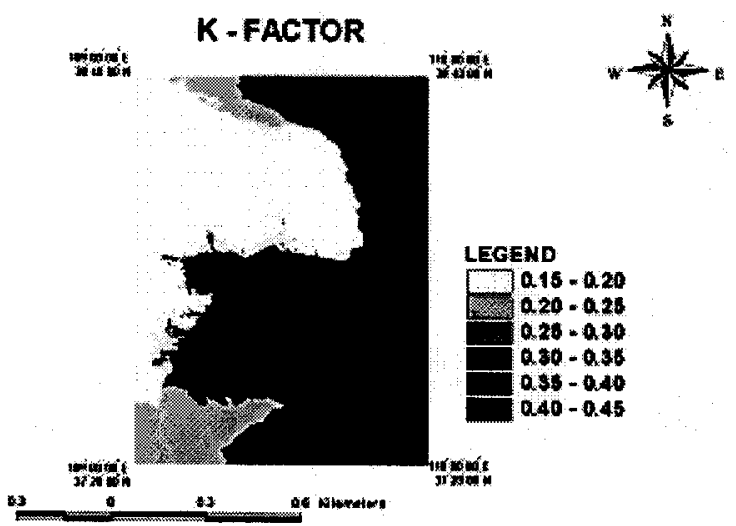

Fig. 1: Soil Erodibility Factor Values (RUSLE_K factor) Map for Study Area

Figure 5 shows the assessment of risk and the present status of water erosion and the input parameters for their calculation. The whole study area is characterized by a high erosivity of present status while the risk is also high. However, in order to reveal the effect of different conditions, recategorization was elaborated.

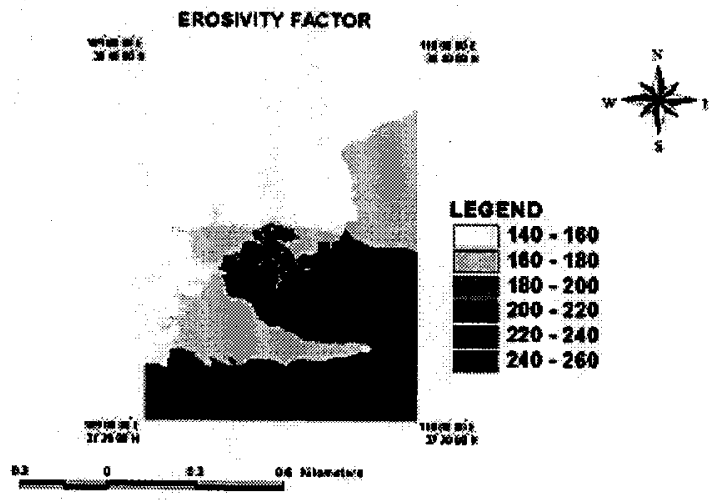

Fig. 2: Rainfall Erosivity Factor Values (RUSLE_R Factor) Map for Study Area

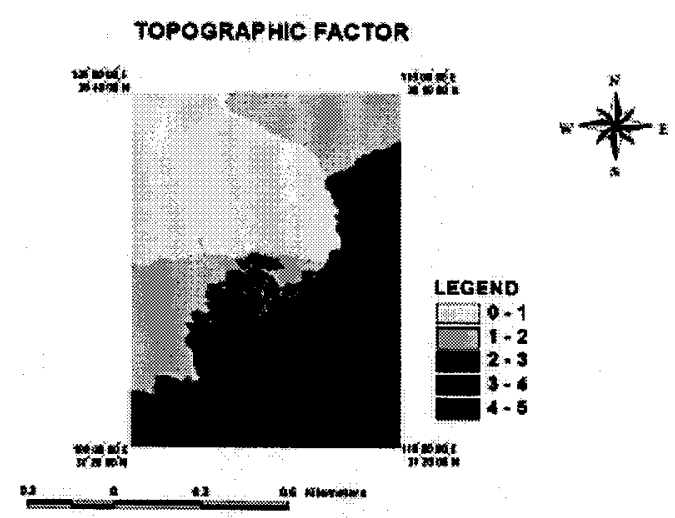

Fig. 3: Topographic (LS) Factor (RUSLE_LS factor) Map for Study Area

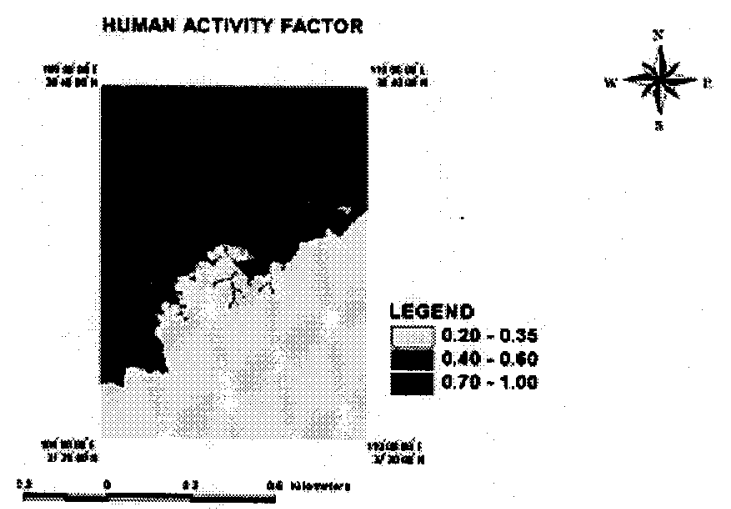

Fig. 4: Human Activity Factor (RUSLE_C\&P) Map for Study Area

The highest values obtained for the present status and risk are found in Mizhi (Slity clay soil). All types are subjected to a higher risk of water erosion compared with the present status. The soil is clay flats characterized by their clay texture and poor drainage conditions. Thus, impermeability surface sealing and 
runoff may occur. These conditions are favorable for both gully erosion and mass movement. Accordingly, values of soil erodibility and soil texture factors are high. The miscellaneous rock land has the characteristics that favor gully formation due to their surface sealing impermeability [23]. Also rugged topographic steep slopes and dissected landscape concentrate runoff.

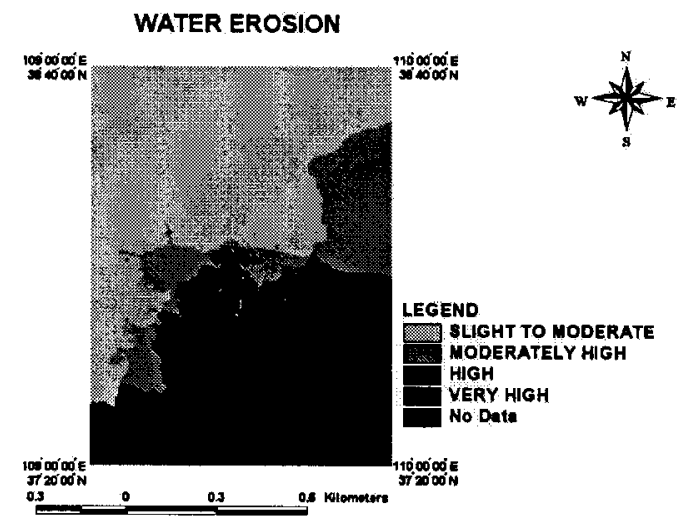

Fig. 5: Risk of Soil Degradation by Water Erosion in the North Shaanxi Province

The study area was mostly characterized by moderate $\left(10-30 \mathrm{t} . \mathrm{ha}^{-1} \mathrm{y}^{-1}\right)$ to severe $\left(30-80 \mathrm{t}^{-h^{-1}} \mathrm{y}^{-1}\right)$ risk and present status values of soil degradation by soil water erosion (Fig. 1). Human activity in the Yulin, Jinbain, Hengshan and Mizhi soils reduce the present state hazard of water erosion. However, water erosion is more pronounced in the areas of Hengshan and Mizhi. As a result of this study, land was divided into four classes according to its vulnerability to erosion and to its vegetation cover.

* Slight to moderate soil water erosion: erosion is occasional, the ratio of the vegetation cover is medium and land is flat or sloppy

* Moderately high soil water erosion: erosion is continuous, the ratio of vegetation cover is high and the slop is medium

* High soil water erosion: erosion is visible continuous, the ratio of vegetation cover is medium and the slope is high

* Very high soil water erosion: various types of erosion are visible, low vegetation cover and the slope gradient is very high

In Table 5, we have the general estimation of soil water erosion in north Shaanxi province. So we conclude that $33.12 \%$ of land area in north Shaanxi province had very slightly to moderate erosion risk, $13.16 \%$ had moderately high erosion risk, $24.44 \%$ had high erosion risk and $29.27 \%$ had very high erosion risk. Without doubt these results show the gravity of soil water erosion problem in the north Shaanxi province.

\section{CONCLUSION}

It is clear from the results of this study that the northern part of Shaanxi Province has been suffering seriously from soil degradation by water erosion resulting from climate variations but mainly from human activities. The modified USEL is a powerful model for the qualitative as well as quantitative assessment of soil erosion intensity for the conservation management. Multi-temporal and multi-spectral remote sensing data have provided valuable and very important factors like $\mathbf{C}$ and $\mathbf{P}$ for this study. Since the crop cover is a powerful weapon to reduce the direct impact of rainfall on soil particles, it can be recommended that all barren lands in local area be converted to agricultural land or forest plantations through proper land reclamation measures. GIS has given a very useful environment to undertake the task of data compilation and analysis within a short period at very high resolution. GPS data can be used for updating the age-old survey of local area topographic map, which is the prime source of data for the Digital Elevation Model and Geo-coding of image.

\section{ACKNOWLEDGEMENTS}

This work was funded by National Key Basic Research and Development Program (Grant No. 2003CB415205).

\section{REFERENCES}

1. Willkie, D.S. and J.T. Finn, 1996. Remote Sensing Imager for Natural Resources Monitoring. Columbia University Press, New York, pp: 295.

2. Lal, R. and B.A. Stewart, 1990. Advances in Soil Science, Soil Degradation, pp: 349. New York: Springer-Verlag.

3. UNEP., 2000. Asia-pacific environment outlook. Environment Assessment for Asia and the Pacific. [http://www.eapap.unep.org/apeo/toc.html].

4. Olson, L., 1985. An integrated study of desrtifcation, Application of remote sensing, GIs and spatial models in semi-arid Sudan, pp: 170. Lund University. Ph.D Thesis. Lund, Sweden.

5. CCICCD., 1997. China Country Paper to Combat Desertification [M]. Beijing: China Forestry Publishing House, pp: 18-31.In: Crippen, R.E., 1990. Calculating the vegetation index faster, remote sensing of environment. 34: 71-73.

6. Jiao Juren, 1996. Integrated Techniques and Practices of Sands Rebuilding by Hydraulic Power. Shaanxi Science and Technology Press.

7. FAO/UNEP and UNESCO, 1979. A provisional methodology for soil degradation assessment, pp: 84. Rome: FAO.

8. Jamaguire, D., M. Goodchild and D. Wrhind, 1991. Geographic Information Systems Principles and 
Application. London: Longman group U.K Limited.

9. Black, G. R., 1965. Bulk Density. In: Black, C.A., D.D. Evans and J.L. White, Eds. Methods of Soil Analysis. Part 1. Agronomy, 9: 379-390.

10. Wischemier, W.H. and D.D. Smith. 1978. Predicting Rainfall Erosion Losses A Guide to Conservation planning. No. 537 Agricultural Handbook. Washington DC: USDA.

11. Renard, K.G., G.R. Foster, G.A. Weesies, D.K McCool and D.C. Yoder, 1997. Predicting Soil Loss by Water. A guide to Conservation planning with the revised universal Soil loss Equation (RUSLE). Number Agricultural handbook number. United States Department of Agriculture (USDA), Washington, DC 20250, 703: 404.

12. Ma Jianwen, C.F., Y. Ma Xue and Z.G. Wang, 2002. Soil Erosion Monitoring in the Upper Yangtze River Basin of China Using ETM Temporal Data. IEEE., pp: 2365-2367.

13. Liu, B.Y., M.A. Nearing and L.M. Risse, 1994. Slope gradient effects on soil loss for steep slopes. Trans. ASAE, 37:1835-1840.

14. Nearing, M.A., 1997. A single continuous function for slope steepness influence on soil loss. Soil Sci. Soc. of America J., 61: 917-919.

15. Quinn, P.F., K.J. Beven, P. Chevallier and $O$. Planchon, 1991. The prediction of hillslope flow paths for distributed hydrological modelling using digital terrain models. Hydrological Processes, 5: 59-79.
16. Desmet, P.J. and G. Govers, 1996a. A GISprocedure for the automated calculation of the USLE LS-factor on topographically complex landscape units. J. Soil and Water Conservation, 51: 427-433.

17. Desmet, P.J. and G. Govers, 1996b. Comparison of routing algorithms for digital elevation models and their implications for predicting ephemeral gullies. Intl. J. Geographic Information Systems, 10: 311331.

18. Desmet, P.J. and G. Govers, 2000. USLE2D.EXE (Release 4.1): User Documentation. Experimental Lab of Geomorphology, Catholic University of Leuven, Leuven.

19. Foster, G.R. and W.H. Wischmeier, 1974. Evaluating irregular slopes for soil loss prediction. Transactions of the ASAE., 17: 305-309.

20. Morgan, R.P.C., 1995. Soil Erosion and Conservation. Longman Scientific and Technical, England, pp: 298.

21. Jabbar Mushtak T., 2003a. Application of GIS to estimate soil erosion using RUSLE. J. Geo-Spatial Inform. Sci., 1: 34-37.

22. Morgan, R.P.C., 1986. Soil Erosion and Conservation. Longman Group UK Limited, pp: 298. Global Positioning System. J. Surveying Eng., 109: 73-80.

23. Jabbar Mushtak T., 2003b. Using remote sensing and GIS techniques to study soil degradation processes in North Shaanxi Province, China. J. China Univ. Geosci., 4: 356-362. 